\title{
Primary hyperlipidemia in children: clinical, biochemistry characteristics and outcome
}

\author{
Nguyen Ngoc Khanh", Vu Chi Dung, Bui Phuong Thao, Can Thi Bich Ngoc, Nguyen Thi Hoan, Nguyen Phu Dat \\ From 8th APPES Biennial Scientific Meeting \\ Darwin, Australia. 29 October - 1 November 2014
}

\section{Background}

Primary hyperlipidemia is genetic dyslipoproteinemia. Without any intervention, cardiovascular diseases and acute pancreatitis may be occurred. The detection and appropriate management of pediatric hyperlipidemia can have a significant impact upon the disease course and can prevent complications.

\section{Objects}

to describe the clinical and biochemical characteristics of hyperlipidemia in Vietnamese children and to evaluate outcome of treatment.

\section{Patients and methods}

From 2007 to 2013, 30 children with primary hyperlipidemia were recruited and were treated with diet and/or lipid-lowering drug therapy at the National Hospital of Pediatrics, Hanoi, Vietnam. Clinical symptoms and biochemical finding, outcome of treatment were studied. Results: Among 30 cases from 28 families, 8 patients were mixed hyperlipidemia (MHL), 13 patients were hypertriglyceridemia (HT) and 9 patients were hypercholesterolemia $(\mathrm{HC})$. Mean age of diagnosis was 5.5 years (1 month - 16 years). The rate of male/female was 13/17. Clinical manifestations included hepatomegaly (4 cases), xanthemas in the knees and elbows (5 cases), "creamy" blood (21 cases). Twenty cases were clinical asymptomatic. $8 / 28$ patients had family history with hyperlipidemia and cardiovascular diseases. Serum cholesterol levels of $\mathrm{HC}$ group was $9.2 \pm 4 \mathrm{mmol} / \mathrm{l}$. Serum triglyceride level of HT group was $23.6 \pm 9.9 \mathrm{mmol} / \mathrm{l}$. MHL group had hypercholesterolemia $(12.1 \pm 4.5 \mathrm{mmol} / \mathrm{l})$ and hypertriglyceridemia $(20.3 \pm 10.5 \mathrm{mmol} / \mathrm{l})$. After interventions, HT group had the best outcome with serum triglyceride level was $10.1 \pm 4.6 \mathrm{mmol} / \mathrm{l}$, next to MHL group with

National Hospital of Pediatrics, Hanoi, Vietnam serum cholesterole level was $5.8 \pm 1.8 \mathrm{mmol} / \mathrm{l}$, and serum triglyceride level was $9.5 \pm 5.2 \mathrm{mmol} / \mathrm{l}$; finally, serum cholesterole level of HC group was $12.4 \pm 5.5 \mathrm{mmol} / \mathrm{l}$. Five infants with HT had the best outcome of treatment: serum triglyceride level decreased from $19-57.6 \mathrm{mmol} / \mathrm{l}$ to $5-10 \mathrm{mmol} / \mathrm{l}$. Two patients with $\mathrm{HC}$ had the worsen results (unchanged blood lipid level).

\section{Conclusions}

Primary hyperlipidemia had poor clinical manifestations and good results of treatment. Screening for primary hyperlipidemia help to prevent premature cardiovascular diseases.

Published: 28 April 2015

\section{doi:10.1186/1687-9856-2015-S1-P124}

Cite this article as: Khanh et al:: Primary hyperlipidemia in children: clinical, biochemistry characteristics and outcome. International Journal of Pediatric Endocrinology 2015 2015(Suppl 1):P124.

Submit your next manuscript to BioMed Central and take full advantage of:

- Convenient online submission

- Thorough peer review

- No space constraints or color figure charges

- Immediate publication on acceptance

- Inclusion in PubMed, CAS, Scopus and Google Scholar

- Research which is freely available for redistribution

Submit your manuscript at www.biomedcentral.com/submit
() Biomed Central 